\title{
Preface, 2002
}

I wrote Tuition Rising for a general audience. No familiarity with economic concepts is required, and the use of notes and citations to references is kept to a minimum. Readers interested in delving more deeply into the issues that I address can go to my home page on the World Wide Web, <http:// www.people.cornell.edu/pages/rge2 $>$. Posted there are links to a reading list for the course on the economics of higher education that I teach at Cornell and an annotated list of sources that I prepared for readers of this book.

Since the hardcover edition was published, tuition at the selective private colleges and universities has continued to rise faster than the rate of inflation. Increases at the selective privates for the years 2000-01 and 2001-02 averaged about 2 percentage points more than the rate of inflation, which falls into the range for the previous fifty years reported in Tuition Rising.

The booming stock market of the late 1990s also saw the endowments of the institutions continue to rise. Indeed, Harvard University's endowment reached more than $\$ 19$ billion on June 30, 2000. One year later, after a period of declining stock market prices, it was still valued at $\$ 18.3$ billion.

Faced with unprecedented increases in wealth and growing public concern about their rate of tuition increases, the wealthiest selective privates increased the generosity of their financial aid policies, with Princeton announcing in February 2001 the elimination of all loans from its financial aid packages. To attract top students, a number of less wealthy selective private institutions increasingly moved in the direction of providing "merit aid" to applicants, which exacerbated concerns about whether these selective institutions would remain accessible to students from a wide variety of socioeconomic backgrounds. Not wanting to move in this direction, a group of presidents from twenty-eight other selective privates issued a joint statement in 
July 2001 pledging to provide financial aid solely on the basis of need and to determine need in a consistent manner across institutions.

Nevertheless, it is not certain that the selective privates as a group will remain accessible to students from low- and lower-middle-income families. The decline in the stock market during the year ending June 30, 2001, which was followed by substantial market disruption and fall after the attacks of September 11, 2001, made it more difficult for the selective private institutions to continue to increase spending from their endowments. The recession that started in 2001 also had an adverse impact on their fund raising for current operations, and the corresponding decline in income of many parents of college-age students increased the financial need of many applicants. As a result of these pressures, many selective private institutions increased their tuitions by 5 percent or more for the 2002-03 academic year, which was more than 3 percent greater than the rate of inflation; this, in turn, still further increased students' financial need. Thus it became increasingly difficult for many selective private institutions to maintain the generosity of their financial aid packages, let alone to continue to enhance them.

Tuition Rising concludes that unless the selective privates as a group maintain their accessibility to students from a wide diversity of backgrounds, by moderating their rates of tuition increases or expanding their provision of need-based financial aid, public concern about tuition hikes is likely to increase. This concern will probably be magnified by the double-digit increases in tuition that occurred at a number of public institutions in 2002-03, as these institutions sought to offset the decline in state appropriations that accompanied the recession. 